\title{
An Investigation into Architectural Creolization of West African Vernacular Mosques
}

\author{
Javid Ghanbari
}

Assistant Professor of Architecture at Shiraz University, Iran

j.ghanbari@shirazu.ac.ir

http://dx.doi.org/10.18415/ijmmu.v8i9.2874

\begin{abstract}
In investigating the influence of religious thoughts on architecture, much attention has been given to divine world-wide religions by the researchers, while indigenous religions have to a great extent been neglected. Ancient tribes in different parts of the world, have, on the basis of their cosmology, shaped beliefs which reflect on their architecture, especially on their sacred buildings. Regarding the Dogons-a well-known and a dominant tribe in West Africa- their Gods, cosmology and beliefs have led to the formation of settlements comprising houses, temples and other types of buildings in accordance with their religious thoughts while also being in harmony with nature. Up on the expansion of Islam throughout Africa, especially West Africa, vernacular mosques are shaped gradually beside shrines making a typology of Islamic architecture which has traces of both Dogon and Islamic architecture within it; While the influence of natural materials and indigenous building techniques should not be neglected. Taking a descriptive-deductive analysis approach, this paper will search for the architectural creolization process and will eventually conclude that West African vernacular mosques inherit their formal and spatial features mostly from Dogon house and pioneer mosques in Medina and their physical features, elements and exterior decorations from Dogon temples.
\end{abstract}

Keywords: Architectural Creolization; Vernacular Mosques; Dogon Architecture; West Africa

\section{Introduction and Research Methodology}

Religion, customs and cosmology are considered almost the same from the viewpoint of archaeology. Mircea Eliade (2014) believes that all the ethnic acts, whether religious or ceremonial are reflections of a deep philosophical ontology which is based on cosmology [1]; all these acts are a repetition of a mythical cosmology that describes the initial creation. In this way, old civilizations have always been renewed through substituting history by mythology. Besides that, religions are expressions of a complicated ontology which in itself is in an inter-relationship with natural and time cycles [2]. Dogon tribe, as an indigenous West African tribe, has shaped their settlements on the basis of their complicated ontology. Dogon people have shaped their villages on the basis of a cosmological structure and erected their houses and other buildings on the basis of clear natural biological and cosmological rules [3]. Dogon's religious thoughts, rooting in their cosmology, have, throughout centuries, lead to shaping sacred spaces such as 
altars and tombs which have their own spatial and physical distinctive features. Through the development of Islam in Africa Mosques as the symbol of Islam and a space for social gathering and community services in non-muslim communities [4] were gradually shaped. Engy Farrag (2017) believes that the characteristics of mosque architecture in non-muslim contexts have to deal with the new environment, culture, traditions and visual vocabulary [5]. Through the development of mosques in western African societies, the process of cultural interaction and change is observed as completely adaptive while we must consider Dogons' architecture and traditions as the dominant culture and religion in this context. Although many of these societies or tribes withstand the cultural change but after few centuries, the emergence of the primitive mosques even in the furthest regions becomes the sign of acceptance of and welcoming Islam [6]. Dogon's primitive vernacular mosques are the results of the same cultural processes, thus the interaction of vernacular Dogon tombs and mosque prototypes, which will be analyzed further in this paper Nezar Alsayyad (2001) categorizes these cultural processes as cultural weathering, cultural hybridity and cultural creolization [7] (Fig. 1)

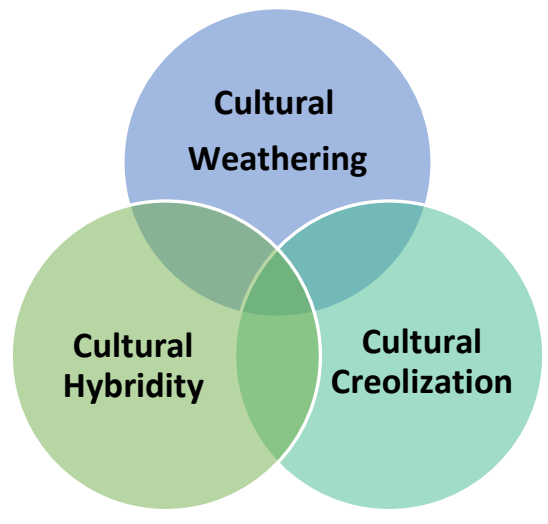

Figure 1. Cultural Processes in Vernacular Architecture Interactions

Source: Author(s) (From [7])

This paper will be based on a descriptive, deductive, and analytical approach. Firstly, it begins with the assumption that the rich Dogon architecture must have influenced the migrating building typologies such as mosques in West Africa; on this basis, Dogons' architecture is thoroughly studied and analyzed. Dogon temples and houses as two main types of buildings and the philosophies behind them are then introduced. Eventually this paper will discuss how vernacular mosques of western Africa are created through a cultural creolization process.

\section{Antecedent Settlements of Dogon Tribe and its Background}

Dogon tribe, as a well-known western African tribe, are mostly living in Bandiagara, a region in Mali. With a population of about three hundred thousand Dogon people are living in about seven hundred villages distributed long along Bandiagara cliffs within a distance of about two hundred kilometers. These cliffs provide a proper natural setting for establishment of settlements. The origin of Dogon tribe is not exactly clear; for long time they had been known as Habe meaning "stranger and secular". It seems that these people originate from ancient Egyptians who had been living in Lybia and then migrated to Burkina Faso and eventually, due to drought, to Bandiagara cliffs around 1490 A.D. [8]. Archeological studies Show that before Dogon tribe, other tribes including Toloy and Tellem cultures had been living in the region respectively related to $2^{\text {nd }}$ to $3^{\text {rd }}$ Centuries B.C and $11^{\text {th }}$ to $15^{\text {th }}$ centuries A.D [9](Fig. 2). 

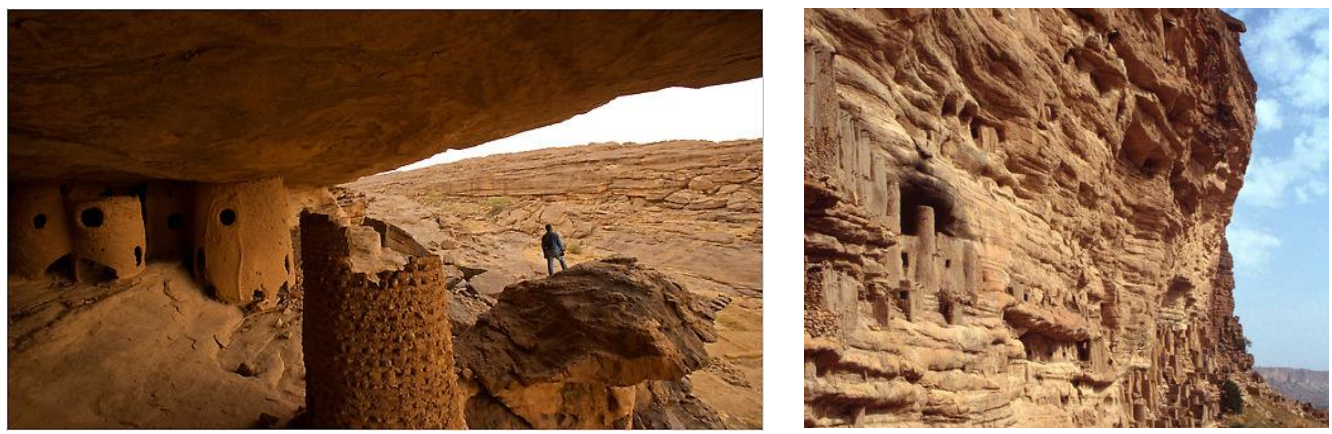

Figure 2. Typical architecture of Toloy and Tellem Civilizations

Source: [9]

\section{Cosmology, Animism and Symbolism in Dogon's Architecture}

Dogons's religious beliefs are mostly based on their complicated cosmology ${ }^{1}$. While the cosmology of the Dogon people represents a natural and ontological philosophy, the ancient cosmology goes beyond metaphysics of ontology. A new branch of science with the name of the ancient astronomy has been created and the experts of this science have shown the correspondence of many temples and cities with the constellations. In the same way, Andrew Collins' book (2014) on stars, rocks, and religion states that all architectural sites are in line with astronomy [10]. Many of the circles or stone paths are, in fact, flat planets, and even the old boundaries between different realms are formed in relation to the constellations, so that the ancient kingdom takes an image of the sky and its stars [2]. Marcel Griaule, who has been studying these people for many years, is confronted with the Dogons' cereal storehouses as the first mythological structure of Gods established in each village [3] (Fig. 3). These buildings are formed on the basis of the cosmos's spatial essence namely circles and squares; geometric shapes that exist in correlation and harmony in celestial mechanics; The circle meaning the sun, its orbit, the moon and other planets, contains the cycle of time and symbolic regeneration, and the square meaning the earth, representing the four directions of the compass and the four indicators of time: the equinoxes and revolutionaries [11]. Grillo also believes that the core of the indigenous religion of Africa is based on the belief that for prosperity, you have to establish and maintain a conscious relationship with cosmos's holy forces [12].

1-In this note, in an investigation into Dogon's religious beliefs, Dogon's Gods and their approaches toward afterlife are introduced.

\section{Dogon's Gods}

Above all paranormal Creatures is Amma who is the super creator God; the owner of life and death; one benevolent entity that masters everything; one who sees everything and knows everyone. Amma is responsible for creating three other creatures for whom the worship is the basis for many totemic rituals. These three Gods are Nommo [the son of Amma and the soul of water], Lebe [the soul of earth and its fertility] and Yurugu [representative of the mythical martyr man]. Dogon people also believe in other souls (spirits) existing in plants, trees and other virgin natural settings. Although Amma is the greatest and all are sacrificed to him, the main core of Dogon's beliefs is based on worshiping ancestors' spirits which could be easily recognizable in Masks, Lebe and Binu rituals and other more general ceremonies related to ancestors' spirits [13].

\section{Death and Afterlife}

Death, as believed by Dogon, is the separation of body from two other parts which together make a whole human entity; these other two parts are Nyama [the vital energy for life] and Kikinu [the soul]. Considering ancestors' worshipping as their core of beliefs, the burial (death-related) ceremonies are given much importance [13]. 


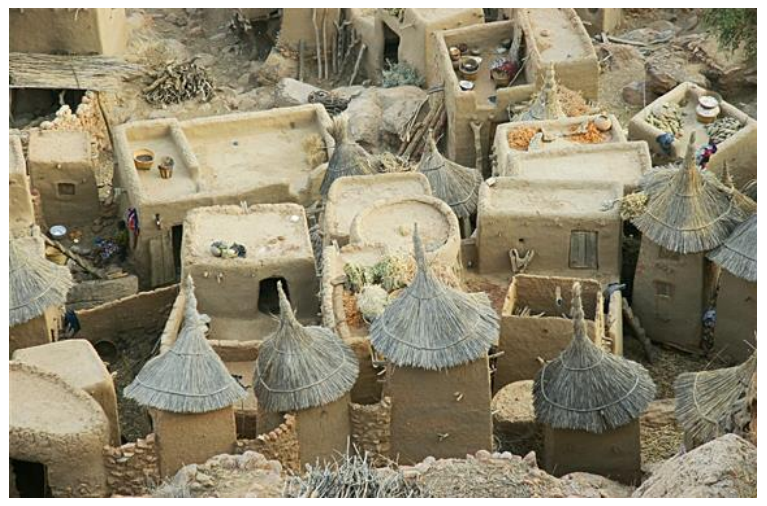

Figure 3. Cereal storehouse in village and reflection of cosmology in its geometrical form. Source: [14]

In addition, the sacred places of Dogon tribe, which are places to respect the ancestors, are built with the same circular and square structures, and include rich symbols such as snake as the symbol of regeneration, the coffin and the eight square map representing the cosmic design, movement and resurrection [3]. On the other hand, numerical symbols are well seen in the architecture of this tribe which all represent a very ancient cosmology. For example, the number eight in Dogons' religious myths and formalities is an important number. According to Dogons' beliefs, there are eight ancestors, the universe has been created within eight days, the deads' shroud is a chessboard with eight squares, and eight square roof containing $8 \times 8$ cubits [each cubit equals to 46 centimeters] [2]. The nature of the sanctity of this number in the myths and customs is completely ontological and has existed in all parts of the ancient world; similarly, each full motion of the Venus star in its orbit lasts eight years, and in its orbit it passes five times the earth's orbit forming a five-pointed star. On the eastern staircase of these warehouses shapes of Venus could be seen; the East is the direction from which the stars rise, and the place from which they calculated their point of movement [3].

Animism has also influenced the formation of some elements of the architecture of these people. In traditional African religions, belief in numerous ghosts is considered entirely animistic. Although there is a belief in a superior God, everyday stress is placed on the worship of smaller spirits. This idea has also influenced the formation of some architectural elements in the villages of Dogon among which one can mention the Crocodile Totem. In the next part of the article, given the cosmological and anthropological effects, the analytic description of the Dogon architecture has been discussed. 


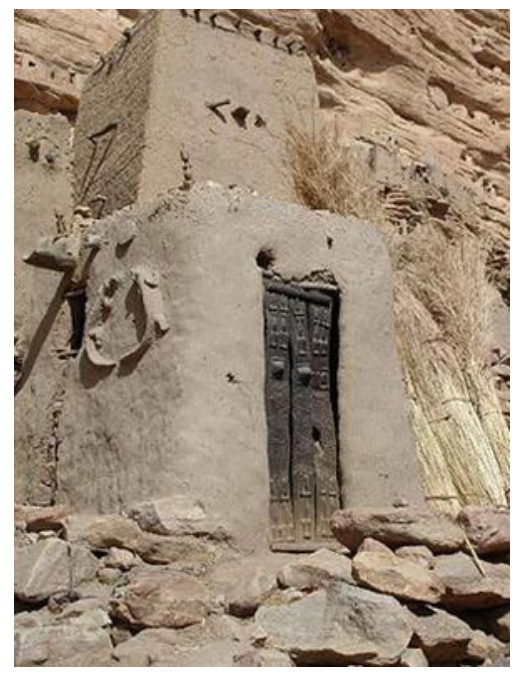

Figure 4. Crocodile Totem

Source: [15]

\section{Analysis of Rural Architecture}

In general, settlements and villages of the Dogon tribe include several buildings such as houses, cereal storages, temples, altars, Togu Nas and Punulu, and in the recent centuries the Mosque. The components of the village can be divided into non-religious architecture, housing architecture and religious architecture. Since this paper will not focus on the analysis of non-religious architecture and special emphasis is put on the analysis of indigenous temples and mosques, in this section of the article the housing architecture and temples has been dealt with and analyzed and the common features of housing architecture and temples with vernacular mosques will be explored.

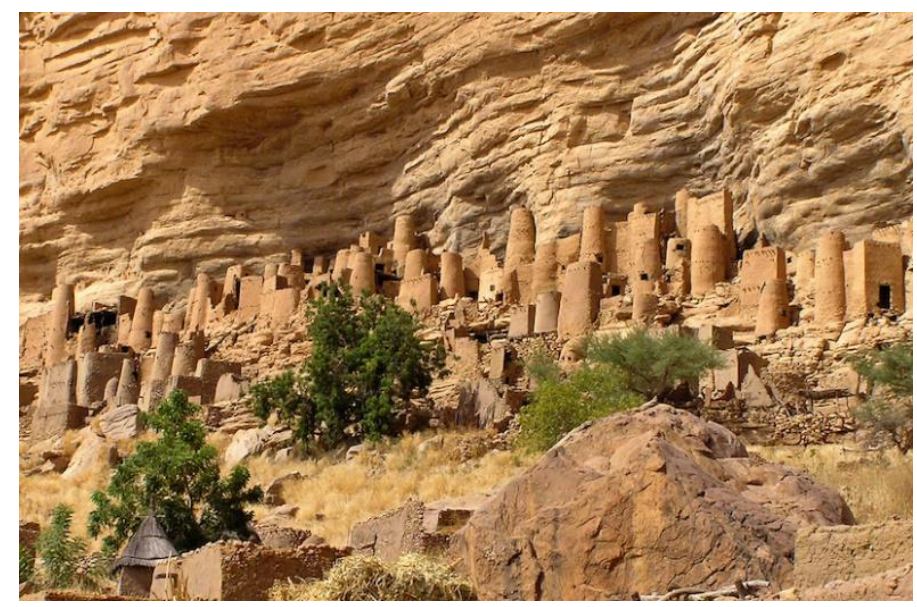

Figure 5. Architecture of the Dogon village along the cliff slopes of Bandiagara Source: [16]

\section{Housing Architecture}

For Dogons the house is not a particular building, but a series of steps that embraces several buildings and is totally related to the individual's social development. For example, a woman lives in her 
father's house until her third child is born, and only lives with her husband at night. It is a hierarchical system in which the house is spread among several buildings until the family reaches a stage that can own its own home [17]. The typical house plan is modeled on the basis of the body of a sleeping woman; the kitchen in the form of a circle, symbolizing the body's respiratory system, is placed at the head of the building; the main body of the living room is the woman's body on both sides of which the storage spaces are located. The entrance to the house also symbolically represents the entrance to the mother's womb [human's former home] some features of which are enclosure and closure, darkness, relative heat, fluidity and humidity and security (Fig. 6). The four spaces around the original space are in fact the symbol of the four pairs of their ancestors. In fact, these four pairs, together with plants, animals, minerals, and Nommo, constitute the celestial arc.

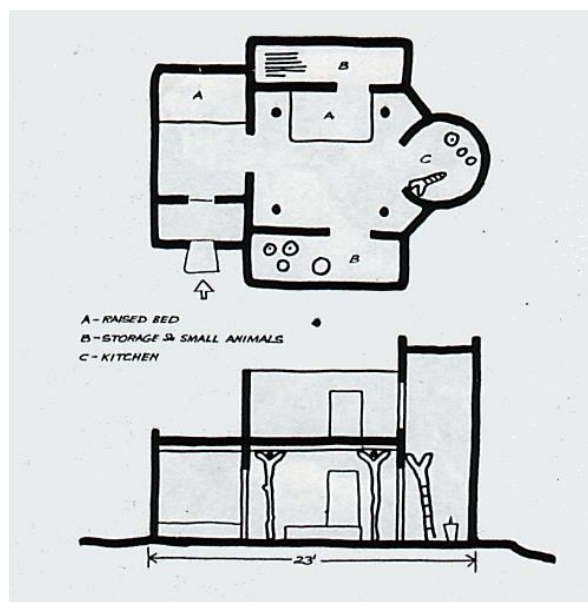

(a)

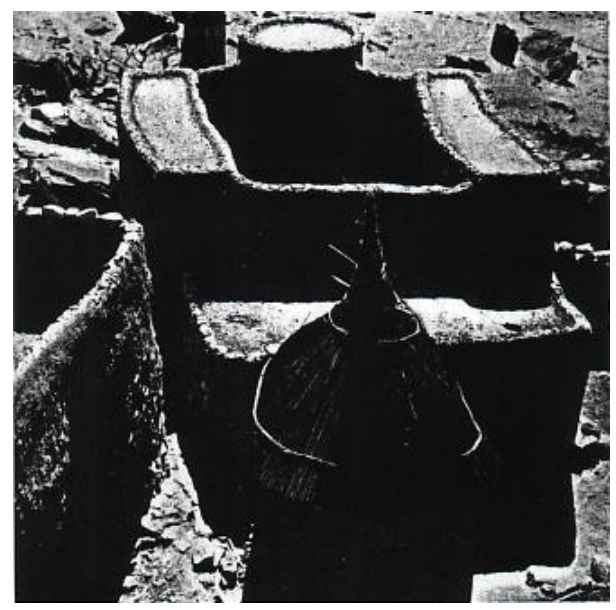

(b)

Figure 6. Plan and section of Dogon house (a) and the image of a typical house (b)

Source: [18]

\section{Altars}

In practice, communication with the supernatural world is formed by gifting or sacrificing food and blood in the altar. These altars exist at different levels of society, for example, at the level of the individual, family, village and region. Below are pictures of some of these alms (Fig. 7) [9].

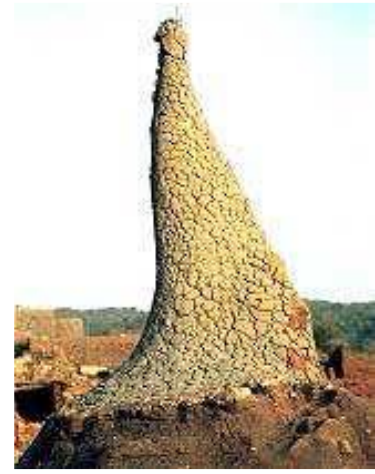

(a)

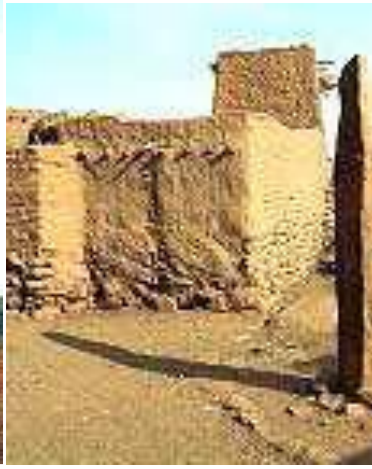

(b)

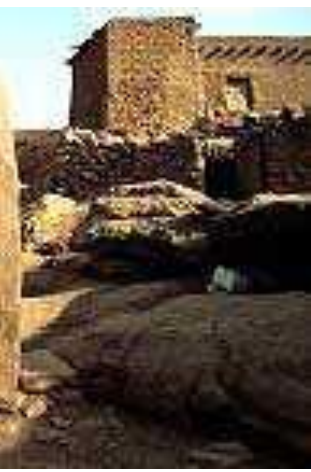

(c)

Figure 7. Symbols of a) Ama, b) Ama and c) Tooru

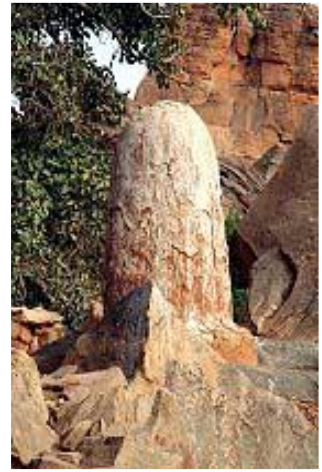

Source: [9]

\section{Temples and the Religious Thoughts Behind}

In general, as in related with the Dogon tribe, architecture, social organization and religion are completely interconnected and the various types of constructions that form the Dogon Village are closely 
aligned with the religious practices that guide their religious life [9]. The Dogons' religion mainly involves the worship of ancestors and spirits with whom they encountered during their gradual migration from their vague land to Bandiagara. In general, there are three different religions among the people of Dogon ${ }^{1}$. The table below illustrates typical temples related to Dogons' rituals.

Table 1. Typical temples related to Dogons' rituals

\section{Reference: Author(s)}

\begin{tabular}{|c|c|c|}
\hline A Lebe Temple & Simple Binu Temple & More Complicated Binu Temple \\
\hline & \\
\hline
\end{tabular}

Spread of Mosques to West Africa

Although the spread of Islam in Africa dates back to the 11th century, until that time it had more impact on urban centers. It is only after the $19^{\text {th }}$ century's sacred battles that Islam develops its roots in the

\section{1 - Awa ritual (Rite of Wagem)}

This ritual is related to the dead, and the purpose is to rearrange the spiritual forces created by the death of Nommo, one of the mythical ancestors of the Dogon people. Members participating in the ceremony perform a special dance at the time of the burial and at the annual ceremony wearing very bright and colored masks. This ritual has 78 types of ritual masks, with their coded messages being at a level beyond the aesthetics and reaching the level of religion and philosophy. The main purpose of this dance is to direct the souls of the dead to their final resting place and sanctify their path to the ancestors [19]. In the research done by the author(s), it seems that this ritual does not have a specific building as a temple.

\section{The Lebe Ritual}

The ritual of Lebe, the god of the earth, refers mainly to the agricultural cycle on earth, and the clergyman is called Hogon. All the villages of Dogon have a Lebe with some earth deposited in its altar space to ensure the continuity of the land's fertility (Fig. 8). According to the beliefs of the Dogon tribe Lebe meets Hogon every night in the form of a large snake licking his skin to bring him purity and induce life energy to him. Hogons are responsible for the cleanliness of the land and are always present in the ceremonies related to agriculture (Gray, 2008).

\section{The Binu Ritual}

Binu is s a totemic ritual and has a complex relationship with sacred places used to worship ancestors, spirits, and sacrifices related to agriculture. Marcel Griaule et al. have come to the conclusion that all of Dogons' main sacred sites are associated with the tale of the myth of the emergence and creation of the world, especially to a God called Nommo. In their cosmology, Nommo was the first living creature created by Ama; Nommo, the god of heaven and the creator of the whole, was later divided into four holy pairs. One of the pairs rebelled against the laws of Ama and caused the entire existence to destabilize. In order to cleanse the world and re-establish its order, Ama sacrificed another Nommo and distributed it in pieces throughout the world. This distribution of parts of the Nommo is considered as the source for the spread of the Binu temples (Fig. 9). In addition to incorporating the components of the body of Nommo, these temples include ghosts of mythical ancestors who lived in the mythical period before the advent of death among human beings. The temples contain holy spaces whose walls are painted with graphic signs and mythical symbols. In these temples, blood sacrifices and wheat gossip are held and people believe that through such a ceremony the goodwill of the ancestors are passed on to them. The Binu ritual uses totems; common totems for ordinary people and special totems for clerics (www.sacredsites.com/africa/mali/dogon.html). 
Dogon's rural areas [9]. The early Muslim community in Mecca did not have a specific place to pray, and the Prophet Muhammad was either at the side of the Ka'bah or at home as the Jama'at prayer house. The Prophet's house in Medina is considered as the prototype for mosque, which in simplest architecture covers all the main elements of the worship space for Muslims. From this viewpoint and considering this mosque as a pioneer model for the development of future mosques, the house of prophet interprets the concept of the house into a mosque and vice versa, which symbolically reflects the integration and presence of religion in all dimensions and layers of life and also looks at religion as such it can't be separated from the whole cosmos; this idea overlaps with traditional African cosmology. The house of the prophet with features such as the simplicity and compatibility with local materials gives a picture of a fully compatible architecture that is free of any decorations [6].

\section{Architectural Analysis of Vernacular Mosques in Futa Toro, Sudan, Mali, and Burkina Faso}

Simplicity is the main feature of Futa Toro vernacular mosques (Fig. 10 a). These mosques, built in the seventeenth, eighteenth, and nineteenth centuries, not only contribute to the study of mud architecture, that reveals the characteristics of a cultural encounter, but also to the recognition of the form of change that marked the passing of Islam from Africa. The characteristics of these mosques during the transition period can be seen in their simplicity, modesty, interaction, and minimalist character. An example of these mosques is the Kobilo mosque; another remarkable mosque is the Mosque of Seno Palel. Although the the latter was built during the passage of Islam, its style is completely different from the Kobilo Mosque. The Seno Palel mosque has a heavy structure without openings except for its three entrances, and in the Kobilo mosque, a tapering cross section is seen in the perimeter wall; the face of the Seno Palel is much lighter and more defenseless than that of Kobilo. In general, the square plan, the eastern porch facing the Qibla, and the three entrance of the Prophet's house are seen as the main elements in the Futa Toro mosques and what is changing is the external shell of the mosque. In some mosques, a corridor space has been added adjunct to the entrance [21].

Many of the architectural features of the Sudanese mosques, such as the heavy pillars with tapered cross sections and numerous columns on the façade rising higher than the roof line (Fig. 11), are similar to the architecture of the Dogon temples. Other similarities are the square plan and the special and unusual altars. Sudanese mosques also inherit features of the various types of buildings in Bandiagara cliffs. For example, one can see the cylinder space of the Dogon house as the most significant element in these mosques; for example, in Kani Kombole and Koporo Kenie Na mosques.

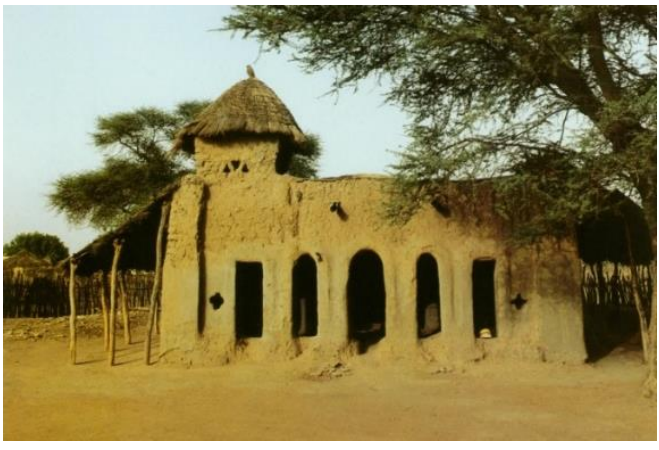

(1)

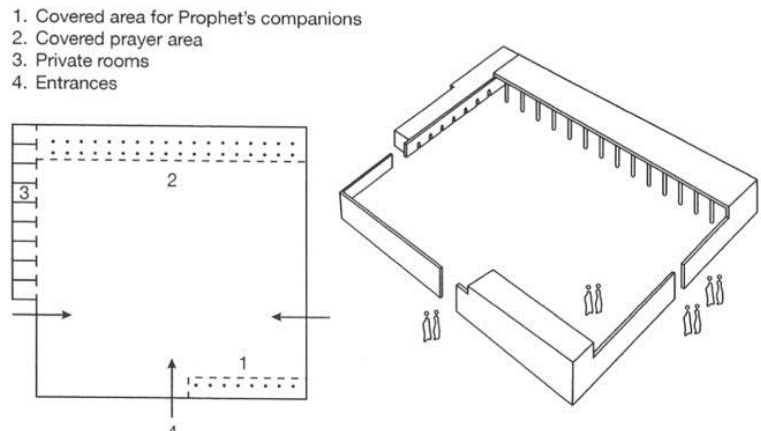

(2)

Figure 10. Similarities between West African Vernaculars Mosques (Typical of Futa Toro) and the House of the Prophet (the first mosque)

Source: [22] 


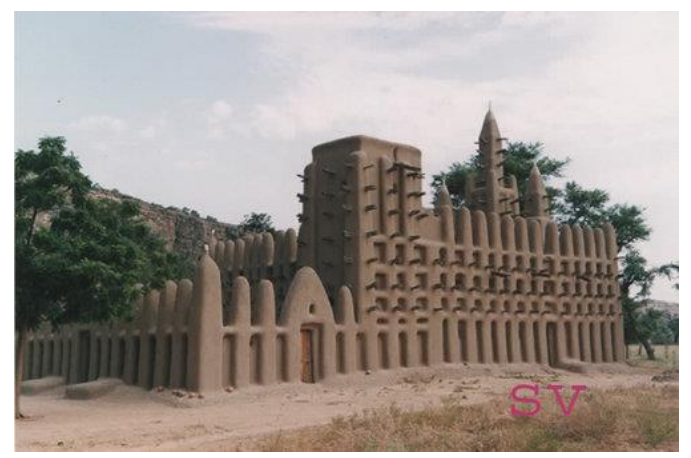

Figure 11. Mosque of Kani Kombole Source: [25]

The Nando mosque is a different example which dates back to the 12 th century. The mosque and several other mosques are more elevated than other buildings, due to being surrounded by dense clusters of the village, and are influenced by existing topography with relatively different plans than other mosques [9].
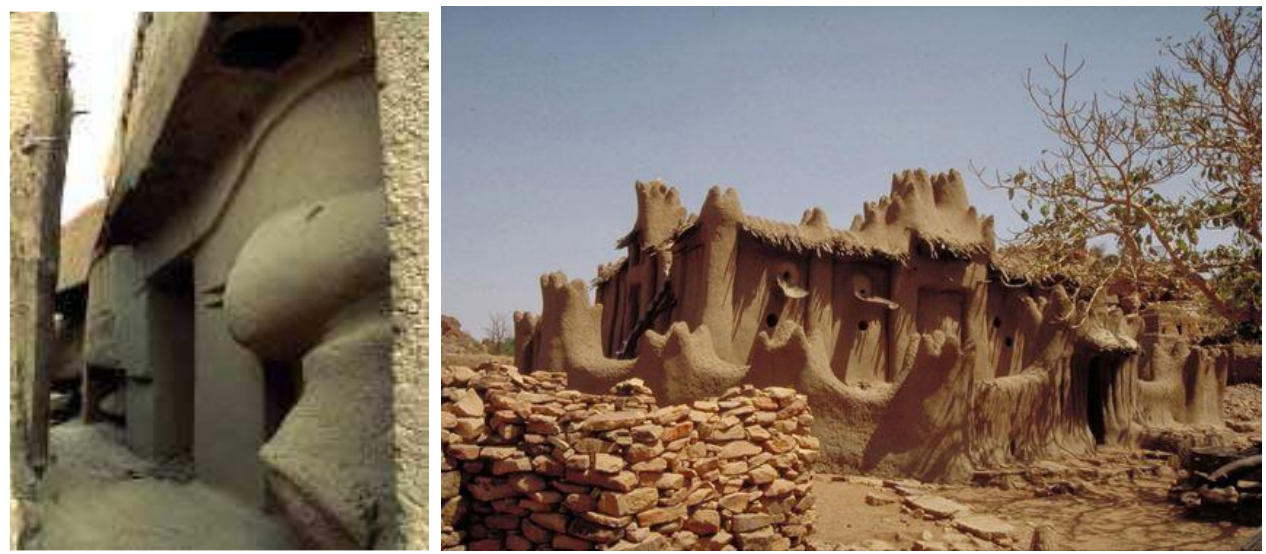

Figure 12. Pictures of the Nando Mosque

Source: [9]

Another significant architectural feature of these mosques is the existence of tall elements with tapering cross sections which lie around the front wall. These spaces within themselves have an empty space that runs to the ceiling and is used as an element of natural light propagation into the interior; this feature is found in the architecture of Dogon's houses in the circular kitchen space.

In general, the depressions on the outer network-shaped wall, the tall empty-spaced elements, and the natural lighting system in these mosques are entirely related to the architecture of Dogon's vernacular temples and houses. As for the first feature, as mentioned above, it is possible to name the mosques Kani Kombole and Kopori Kenie Na. For the third feature, indirect lighting, we can mention Bobo, Sogou and Dimmbal mosques. But the second feature, the use of the relatively tall empty-spaced elements, is a common feature of all these mosques, although its forms are very diverse and range from narrow columns to heavy conic ones, which can be seen in the Koulekonga Mosque [6]. 


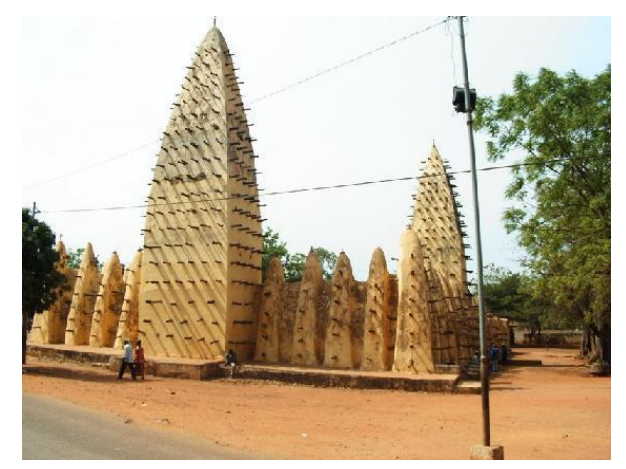

Figure 13. La Grand mosque in Bobo-Dioulasso, $\underline{\text { Burkina Faso }}$

Source: [23]

Given that the Dogon people settled in the Bandiagara cliffs from the eleventh century, and that they initially showed great resistance to Islam, it seems that these features and their symbolism are more closely related to the cosmogony of the Dogon people, and there is not much connection with the development of Islam in the West [6].

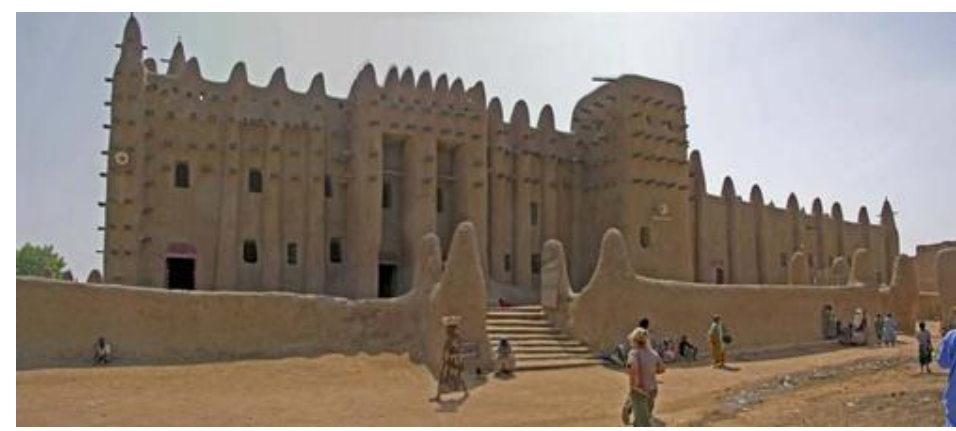

(a)

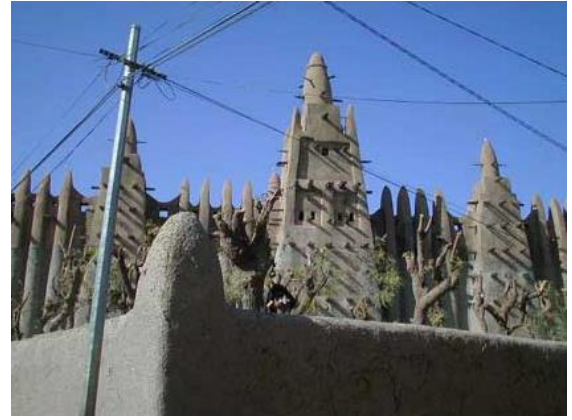

(b)

Figure 14. Mopti Mosque (a) and Djenné Mosque (b) in Mali

Source (a): [26]

Source (b): [24]

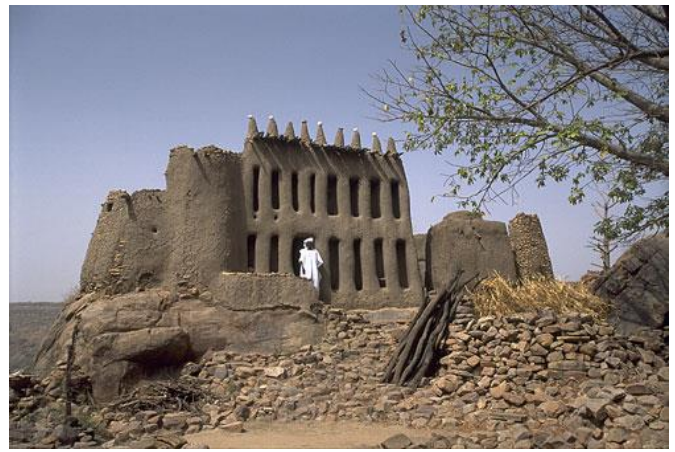

(a)

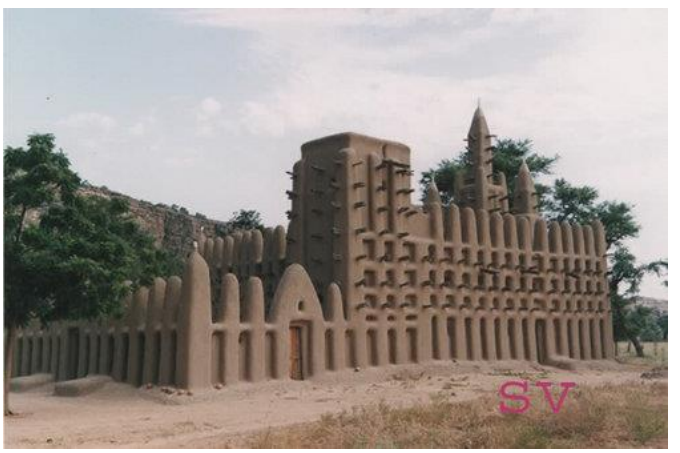

(b)

Figure 15. Comparison of the outer shell of and a Binu temple (a) and the Kani Kombole mosque (b) 
Among the architectural features mentioned before, attention to the type of lighting is more important than other features that are not only visible in homes and temples, but also in mosques. After the establishment of the first model of the Dogon temple, the Dogon house was used as an ideal example for the construction of their mosques, because these houses have a circular projected space in the east, as well as an entrance to the west, which are entirely the requirements for building a mosque (placement of the qibla in the east direction). This space spreads natural light through the opening inside the ceiling, indirectly, on the walls of an empty semicircular space, which now houses the altar instead of the kitchen.

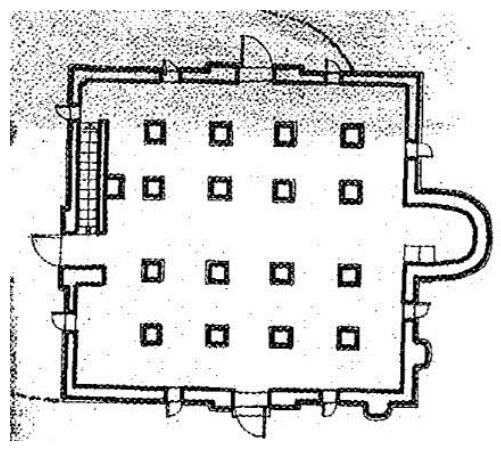

(a)

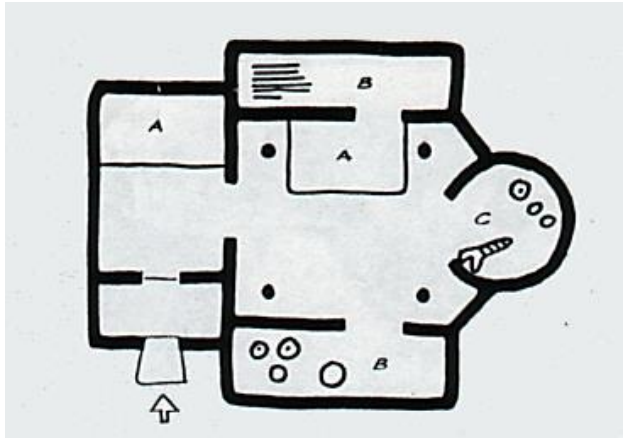

(b)

Figure 16. Comparison of the Dogon House Plan (a) with the plan of a typical Western African mosque(b)

The attention to natural light in the altar can be seen as the significance of light as a symbol of truth both in Islam and in other religions [6]. At a time when the radiation is more intense on the eastern wall facing the altar, it creates a circle of light on the word Allah written on this wall; an example of this can be found in the mosques of Guede the Tielao and Halwar.

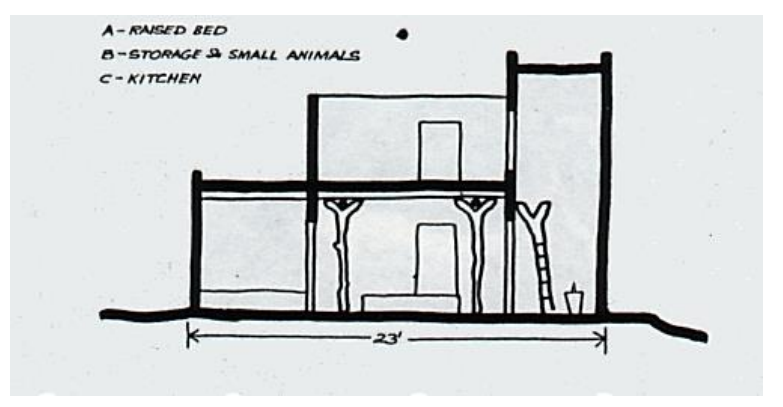

(a)

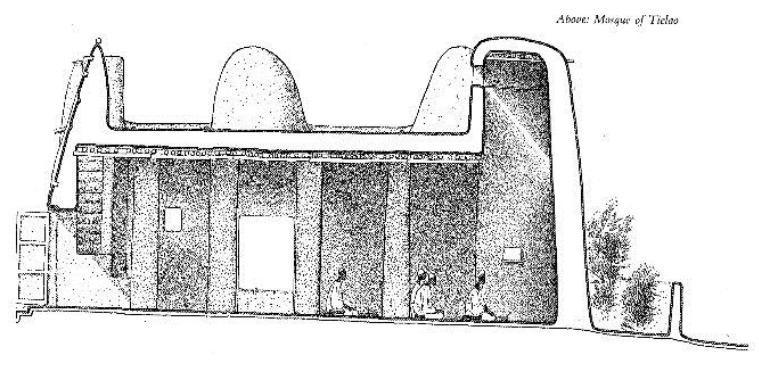

(b)

Figure 17. Comparison of the cross section of the Dogon house (a) and a typical West African vernacular mosque (b)

\section{Conclusion}

Perhaps it can be argued that animism has influenced the Dogon rites as well as the elements and decorations within the spaces of their temples rather than the architectural form of the village components, and the form of architecture is more influenced by their cosmology. But after the arrival of the mosques, the existing forms change relatively in function and nature. In general, vernacular mosques of West Africa, from the viewpoint of architectural form, regarding their combined form, correspond to the Dogons' house; (however, it should also be noted that the spatial essence, plurality of spaces and the simplicity of these 
mosques correspond to the mosque of Medina). From spatial viewpoint, the arrangement of spaces and plan hinges, these mosques are also more in line with the Dogons' house. In terms of construction technology, all three types of constructions are similar sharing similar earth building technologies. In the exterior and outer shell, elements such as earth pillars with their height exceeding over the roof, as well as the rhythm of shadow, projections and depressions and the use of triangular elements in the façade are noticed as the common features between temples and mosques. From the viewpoint of natural lighting, although the mosques are matched with both houses and temples, they are more consistent with houses sharing indirect lighting systems. As a conclusion, the architectural features of the vernacular West African creole mosques can be summed up in comparison with the Dogons' houses and temples in the following table:

Table 1. Common Characteristics of West African Native Mosques with the Dogon Architecture Reference: Author(s)

\begin{tabular}{|c|c|c|c|c|c|c|}
\hline$\stackrel{0.00}{:}$ & Form & $\begin{array}{c}\text { Spatial } \\
\text { Arrangem } \\
\text { ent }\end{array}$ & Plan Geometry & $\begin{array}{c}\text { Constructi } \\
\text { on } \\
\text { Technolog } \\
\mathbf{y}\end{array}$ & Façade Details & $\begin{array}{l}\text { Natural } \\
\text { Lighting }\end{array}$ \\
\hline है & $\begin{array}{l}\text { Pure cubic } \\
\text { form (with an } \\
\text { exception } \\
\text { having two } \\
\text { cylinders in its } \\
\text { two corners) }\end{array}$ & $\begin{array}{l}\text { Single } \\
\text { space }\end{array}$ & $\begin{array}{l}\text { Square and } \\
\text { rectangular - } \\
\text { squares and } \\
\text { pairs of corners } \\
\text { in the corner }\end{array}$ & $\begin{array}{c}\text { Earth } \\
\text { building } \\
\text { Technologi } \\
\text { es }\end{array}$ & $\begin{array}{l}\text { Use of earthen } \\
\text { pillars higher than } \\
\text { the ceiling in the } \\
\text { facade - Using } \\
\text { triangular } \\
\text { elements in the } \\
\text { facade-facade is } \\
\text { covered and } \\
\text { highlighted with a } \\
\text { shadow rhythm }\end{array}$ & $\begin{array}{l}\text { Lighting is } \\
\text { mainly direct }\end{array}$ \\
\hline 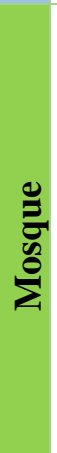 & $\begin{array}{l}\text { Combined } \\
\text { cylinder form } \\
\text { (or cone or } \\
\text { vertical } \\
\text { rectangular } \\
\text { cube) with } \\
\text { cube }\end{array}$ & $\begin{array}{l}\text { Multi- } \\
\text { spaced with } \\
\text { a distinct } \\
\text { space }\end{array}$ & $\begin{array}{l}\text { Combination of } \\
\text { square and } \\
\text { circle/ or } \\
\text { Combination of } \\
\text { square and } \\
\text { square }\end{array}$ & $\begin{array}{c}\text { Earth } \\
\text { building } \\
\text { Technologi } \\
\text { es }\end{array}$ & $\begin{array}{l}\text { Use of earthen } \\
\text { pillars higher than } \\
\text { the ceiling in the } \\
\text { facade - Using } \\
\text { triangular } \\
\text { elements in the } \\
\text { facade-facade is } \\
\text { covered and } \\
\text { highlighted with a } \\
\text { shadow rhythm }\end{array}$ & $\begin{array}{l}\text { The darkness of } \\
\text { the main space, } \\
\text { except for } \\
\text { lighting in the } \\
\text { altar (in some } \\
\text { indirect } \\
\text { mosques and in } \\
\text { a few direct } \\
\text { mosques) }\end{array}$ \\
\hline$\stackrel{\mathscr{2}}{\stackrel{0}{0}}$ & $\begin{array}{l}\text { Combined } \\
\text { cylinder and } \\
\text { cube form }\end{array}$ & $\begin{array}{l}\text { Multi- } \\
\text { spaced with } \\
\text { a distinct } \\
\text { space }\end{array}$ & $\begin{array}{l}\text { Combination of } \\
\text { square and circle }\end{array}$ & $\begin{array}{c}\text { Earth } \\
\text { building } \\
\text { Technologi } \\
\text { es }\end{array}$ & $\begin{array}{l}\text { Fully smooth } \\
\text { exterior }\end{array}$ & $\begin{array}{l}\text { The darkness of } \\
\text { all spaces } \\
\text { except the } \\
\text { lighting in the } \\
\text { kitchen (mostly } \\
\text { indirect) }\end{array}$ \\
\hline
\end{tabular}




\section{References}

[1]. Eliade, Mircea, 2014, Myth, Religion, and History, Published by Routledge.

[2]. Lundwall; J. Knight. 2006. The Sacred Power of the World: Dogon Cosmology as the Prototypical Heirocentric Universe.

[3]. Griaule, Marcel. 1965. Conversations with Ogotemmeli. New York, Oxford UP.

[4]. Kahera, A., Abdumalik, L. and Anz Kahera, C., 2009, Design Criteria for Mosques and Islamic Centers, Art, Architecture and Worship.

[5]. Farrag, E. 2017. Architecture of Mosques and Islamic Centers in Non-Muslim Context. Alexanderia Engineering Journal. 56: 613-620. DOI: https://doi.org/10.1016/j.aej.2017.08.001.

[6]. Bourdier, Jean-Paul. 1991. Houses of Light, an Analysis of the Rural Mosques of Senegal and Mali. Journal of Mimar. Vol 39: 61-67.

[7]. Alsayyad, Nezar. 2001, Foreword of Vernacular Architecture in the $21^{\text {st }}$ Century, Edited by Lindsay Asquith and Marcel Vellinga.

[8]. Gray, Martin. 2014. Places of Peace and Power.

[9]. Blom, Huib et al. 2016. Book on Dogon Architecture. From: <www.dogon-lobi.ch> (retrieved November $\left.10^{\text {th }}, 2016\right)$.

[10]. Collin, Andrew, 2014, Genesis of the Gods: The Temple of the Watchers and the Discovery of Eden, Published by: Bear \& Company; Illustrated edition.

[11]. Nibley, Hugh. 1994. Ancient Documents and the Pearl of Great Price. Edited by Robert Smith. Salt Lake City, Utah Deseret Book.

[12]. Grillo, Laura. 1999. African Religions. Encyclopedia of Women and World Religion, Macmillan Reference USA. 2: 6-11.

[131]. URL: http://www.everyculture.com/Africa-Middle-East/Dogon-Religion-and-ExpressiveCulture.html. (retrieved November $10^{\text {th }}, 2019$ ).

[14]. URL: http://en.wikipedia.org/wiki/Image:DogonVillage.jpg. (retrieved November $10^{\text {th }}, 2019$ ).

[15]. URL: http://en.wikipedia.org/wiki/Dogon. (retrieved November 10 ${ }^{\text {th }}, 2016$ ).

[16]. URL: https://www.touropia.com/incredible-city-cliffs. (retrieved September 15 ${ }^{\text {th }}, 2019$ ).

[17]. Merkus, E. 2015. An Introduction to the Psychology of Architecture. From <http://sociolingo.wordpress.com/2007/02/11/dogon-architecture/> (retrieved November 19 ${ }^{\text {th }}, 2019$ ).

[18]. URL: http://sociolingo.wordpress.com/2007/01/14/mali-dogon-architecture/. (retrieved November $\left.10^{\text {th }}, 2019\right)$. 
[19]. Fortuna, Nick. 2015. The Religion of the Dogon. From <http://dickinsg.intrasun.tenj.edu/diaspora/dogon.html>. (Retrieved: 20/10/2016).

[20]. URL: http:// www.sacredsites.com/africa/mali/dogon.html. (retrieved September $15^{\text {th }}, 2019$ ).

[21]. Bourdier, Jean-Paul. 1993. Rural Mosques of Futa Toro.Journal of African Arts. 26(3): 32-45. DOI: $10.2307 / 3337150$

[22]. URL: http://www.jstor.org/pss/3337150. (retrieved November 10 $0^{\text {th }}, 2019$ ).

[23]. URL: http://members.virtualtourist.com/m/p/m/32747. (retrieved November $10^{\text {th }}, 2019$ ).

[24]. URL: http://homepage.mac.com/melissaenderle/mali/pages/mosquemopti.html. (retrieved November $\left.10^{\text {th }}, 2019\right)$.

[25]. URL: http://www.panoramio.com/photo/3086. (retrieved Septrember 10 ${ }^{\text {th }}, 2019$ ).

[26]. URl: http://www.panoramio.com/photo/5115028. (retrieved September $\left.15^{\text {th }}, 2019\right)$.

\section{Copyrights}

Copyright for this article is retained by the author(s), with first publication rights granted to the journal.

This is an open-access article distributed under the terms and conditions of the Creative Commons Attribution license (http://creativecommons.org/licenses/by/4.0/). 